\title{
Perbedaan Kualitas Sekolah Unggulan di Kabupaten Banyuwangi Setelah Diberlakukannya Sistem Zonasi Studi Kasus di SMPN 1 Banyuwangi
}

\author{
Differences in the Quality of Favorite Schools in Banyuwangi Regency After the Implementation of \\ the Zoning System (Case Study at SMPN 1 Banyuwangi) \\ Marita Mutiara Sinsyi ${ }^{*}$, Yaya Setiadi ${ }^{2}$ \\ ${ }^{1,2}$ Politeknik Statistika STIS \\ Jalan Otto Iskandardinata No. 64C, RT 001/RW 004, Bidara Cina, Jatinegara, Jakarta Timur \\ E-mail: 211709812@gmail.com
}

\begin{abstract}
ABSTRAK
Setelah diberlakukannya sistem zonasi, sekolah unggulan tidak dapat lagi menyeleksi siswa yang berprestasi guna mempertahankan kualitasnya. Tujuan penelitian ini adalah untuk mengetahui perbedaan kualitas sekolah unggulan di Kabupaten Banyuwangi setelah diberlakukannya sistem zonasi dengan analisis Wilcoxon Signed Rank Test dan mengkonfirmasi dimensi serta indikator kualitas sekolah unggulan di Kabupaten Banyuwangi dengan CFA. Responden dalam penelitian ini adalah semua guru yang sudah mengajar sejak sebelum diberlakukannya sistem zonasi dan masih aktif mengajar hingga saat ini. Variabel yang digunakan yaitu sarana dan prasarana, guru, manajemen sekolah, dan proses pembelajaran. Hasil yang diperoleh yakni hanya proses pembelajaran saja yang berbeda antara sebelum dan setelah zonasi. Dimensi guru merupakan dimensi yang paling memiliki korelasi kuat dengan kualitas sekolah unggulan SMPN 1 Banyuwangi di Kabupaten Banyuwangi.
\end{abstract}

Kata kunci: Sistem zonasi, kualitas sekolah, wilcoxon signed rank test, CFA

\begin{abstract}
After the implementation of the zoning system, the favorite school they can't select smart students in order to maintain their quality anymore. This study aims to determine difference the quality of favorite schools in Banyuwangi after the implementation of the zoning system using Wilcoxon Signed Rank Test and to confirm the dimensions and indicators of the quality of favorite schools in Banyuwangi using CFA. The respondents in this study are all teachers who have taught since before the implementation of the zoning system and they are still actively teaching until now. The variables used are facilities and infrastructure, teachers, school management, and the learning process. The results is that only the learning process is different between before and after zoning. The teacher is the most dimension that has strong correlation with the quality of favorite school of SMPN 1 Banyuwangi in Banyuwangi.
\end{abstract}

Keywords: Zoning system, school quality, wilcoxon signed rank test, CFA

\section{PENDAHULUAN}

Kualitas pendidikan di Indonesia masih tergolong rendah. Hal ini dapat digambarkan dengan peringkat Education Index Indonesia yang berada pada urutan ke-111 dari 189 negara pada tahun 2017. Awalnya penerimaan siswa baru di Indonesia dilakukan dengan menggunakan sistem rayonisasi yang lebih mengutamakan pencapaian dalam bidang akademik. Widyastuti (2020) mengungkapkan dua keluhan orang tua tentang sistem rayonisasi yang akhirnya membuat sistem zonasi diberlakukan. Keluhan pertama, mereka harus menempuh jarak jauh untuk ke sekolah karena nilai anak mereka tidak memenuhi kriteria dari sekolah terdekat. Keluhan kedua, mereka kesulitan dalam membayar biaya sekolah. Hal ini terjadi pada orang tua yang terpaksa menyekolahkan anaknya di sekolah swasta, akibat tidak diterima di sekolah negeri. Oleh karena itu, pemerintah Indonesia menerapkan kebijakan baru guna meningkatkan kualitas sekaligus memeratakan pendidikan Indonesia, yaitu sistem zonasi.

Setelah sistem zonasi diberlakukan, pada tahun 2018 peringkat Education Index Indonesia menjadi ke112 dari 189 negara. Selain itu, pada saat pelaksanaannya terdapat beberapa pihak yang merasa dirugikan dengan adanya kebijakan ini, salah satunya yaitu sekolah unggulan. Dalam penelitiannya, Pradewi dan Rukiyati (2019) menyimpulkan bahwa sistem zonasi dapat menurunkan kualitas sekolah. Nurlailiyah (2019) menyebutkan beberapa keluhan guru diantaranya siswa yang masuk setelah diberlakukannya sistem zonasi memiliki motivasi belajar yang rendah, susah untuk disiplin dan memahami materi, serta ramai saat didalam 
kelas. Menurut Ula dan Lestari (2019), dampak negatif yang dirasakan sekolah sebesar 79 persen. Tingginya dampak negatif ini, dikhawatirkan akan menurunkan kualitas sekolah secara drastis.

Selama ini, praktek pendidikan di Indonesia hanya menekankan pada aspek kecerdasan intelektual (Supardi, 2015). Oleh karena itu, ketika Penerimaan Peserta Didik Baru (PPDB) menggunakan sistem zonasi yang tidak memperhitungkan capaian akademik, banyak sekolah yang merasa dirugikan karena tidak dapat menyeleksi siswa yang berprestasi guna meningkatkan atau mempertahankan kualitasnya. Padahal, Badan Standar Nasional Pendidikan (BSNP) telah menetapkan delapan Standar Nasional Pendidikan (SNP) sebagai acuan kualitas pendidikan di sekolah. Sehingga sekolah dapat meningkatkan atau mempertahankan kualitasnya melalui berbagai aspek. Dalam rangka meningkatkan kualitasnya, sekolah perlu menyusun strategi yang tepat dan sesuai. Namun, karena aspek dalam kualitas sekolah cukup banyak, maka sebelum menyusun strategi perlu didahului oleh identifikasi faktor-faktor yang dominan dalam sekolah.

Kualitas pendidikan di Indonesia, khususnya Sekolah Menengah Pertama (SMP), masih belum memenuhi capaian SNP. Skor Peta Mutu Pendidikan (PMP) SMP Indonesia hanya sebesar 5,38. Skor ini masih berada dibawah skor minimum capaian SNP, yakni sebesar 6,67. Berdasarkan Gambar 1, terlihat bahwa radar yang paling kecil adalah radar milik pendidik dan tenaga kependidikan serta sarana dan prasarana. Menurut Direktur Jenderal Guru dan Tenaga Kependidikan Kementerian Pendidikan dan Kebudayaan (Dirjen GTK Kemendikbud), Supriano (2018), terdapat empat hal yang harus diperhatikan dalam meningkatkan mutu pendidikan, yaitu kebijakan dalam manajemen sekolah, kepemimpinan kepala sekolah sebagai tenaga kependidikan, infrastruktur sekolah, dan proses pembelajaran.

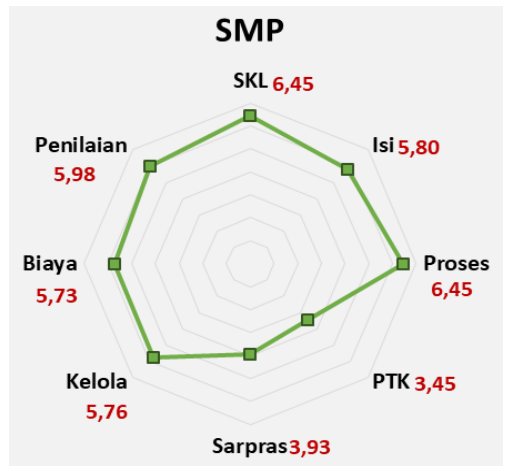

Sumber: Kemendikbud, 2019

Gambar 1. Radar skor PMP 2018.

Berdasarkan data Badan Pusat Statistik (BPS) tahun 2018, terdapat tiga (3) provinsi yang memiliki jumlah siswa pada jenjang SMP lebih dari satu juta siswa, yakni Jawa Barat, Jawa Timur dan Jawa Tengah. Dari ketiga provinsi tersebut, Jawa Timur memiliki kualitas pendidikan yang paling baik. Hal ini didasarkan pada persentase guru yang layak mengajar di Jawa Timur lebih unggul dibanding provinsi yang lain. Selain itu, rasio murid-guru, rasio murid-rombongan belajar, dan rasio murid-sekolah di Jawa Timur paling kecil diantara ketiganya. Pada tahun 2017, dimana sistem zonasi belum diberlakukan, Provinsi Jawa Timur memiliki Indeks Pembangunan Pemuda (IPP) domain pendidikan sebesar 66,67. Nilai ini sudah melampaui nilai IPP domain pendidikan nasional Indonesia. Namun, pada tahun 2018, setelah diberlakukannya sistem zonasi, indeks Jawa Timur turun menjadi 63,33 dan berada dibawah nilai indeks nasional.

Berdasarkan data Kemdikbud tahun 2019, terdapat lima (5) kabupaten di Jawa Timur dengan jumlah guru terbanyak, antara lain Kota Surabaya, Kabupaten Jember, Kabupaten Malang, Kabupaten Sidoarjo, dan Kabupaten Banyuwangi. Selain itu berdasarkan data BPS, kelima kabupaten dan kota tersebut sama-sama memiliki jumlah siswa pada jenjang SMP terbanyak. Diantara kelima kabupaten tersebut, Kabupaten Banyuwangi memiliki persentase guru PNS tertinggi dan juga rasio-murid guru terkecil. Sebanyak 80 persen sekolah di Kabupaten Banyuwangi telah memiliki akreditasi minimal B. Hal ini menandakan bahwa Kabupaten Banyuwangi memiliki kualitas pendidikan yang unggul. Namun dari kelima kabupaten dan kota tersebut, hanya indeks pendidikan Kabupaten Banyuwangi yang tidak mengalami peningkatan dari tahun 2017 ke tahun 2018.

Maka dari itu, menarik untuk ditelti bagaimana kualitas sekolah unggulan di Kabupaten Banyuwangi setelah diberlakukannya sistem zonasi. Selain itu, ingin mengkonfirmasi indikator dan dimensi kualitas sekolah unggulan di Kabupaten Banyuwangi. Dengan demikian, sekolah unggulan dapat mengetahui dan melakukan evaluasi faktor-faktor apa saja yang mungkin perlu ditingkatkan guna mempertahankan kualitas sekolahnya. 
Nurlailiyah (2019) melakukan penelitian terhadap perilaku siswa SMP di Yogyakarta dengan menggunakan pendekatan kualitatif. Dulu guru mengajar di SMPN merasa ringan, karena sekali diterangkan siswa sudah memahami. Namun, dengan sistem zonasi guru mengajar dengan ekstra, bahkan terkadang guru tidak mengajar materi melainkan mengajari etika dan sopan santun. Penelitian Ula dan Lestari (2019) bertujuan untuk memaparkan dampak dari pelaksanaan sistem zonasi di Kota Malang. Hasil yang diperoleh dengan menggunakan metode kualitatif yaitu dampak negatif bagi sekolah sebesar 79 persen dan dampak positifnya hanya 21 persen. Di sisi lain dampak positif sistem zonasi yang dirasakan masyarakat sebanyak 36 persen dan 64 persen lainnya menganggap sistem zonasi belum memiliki dampak positif. Nur, Harun, dan Ibrahim (2016) melakukan penelitian yang bertujuan untuk mengetahui manajemen sekolah dalam meningkatkan mutu pendidikan meliputi perencanaan program sekolah, pelaksanaan program sekolah, dan hambatan yang dihadapi. Hasil yang diperoleh untuk perencanaan, mencakup kebutuhan guru, pengadaan media, pengembangan laboratorium dan perpustakaan, sistem penilaian, dan kegiatan ekstrakurikuler. Untuk pelaksanaan, strategi yang diterapkan yaitu sosialisasi program, pemecahan masalah, peningkatan mutu, serta pemantauan dan evaluasi pelaksanaan program sekolah. Sementara hambatan yang dialami yaitu kurangnya partisipasi masyarakat.

\section{METODE}

Muniarti et al. (2016), apabila sarana dan prasarana tersedia dengan lengkap dan dalam kondisi yang baik akan mendukung anak untuk giat belajar dan memperoleh hasil yang baik. Sehingga dapat disimpulkan jika sarana dan prasarana yang baik akan menghasilkan kualitas pendidikan yang baik pula. Samtono menguraikan bahwa peningkatan kualitas guru dapat meningkatkan mutu sekolah dan juga pendidikan secara nasional (dalam Hidayat, 2014). Sekolah yang mampu melakukan manajemen terhadap program, sumber daya manusia, dana, sarana, informasi, dan suasana dengan baik, maka akan mencapai mutu pendidikan yang baik pula (Nurkuntari, 2016). Saputra (2015) mengatakan bahwa dengan adanya proses pembelajaran yang baik, maka akan tercipta keberhasilan siswa dalam belajar, sehingga dapat meningkatkan kualitas sekolah.

Metode analisis yang digunakan pada penelitian ini adalah analisis deskriptif dan analisis inferensia dengan Wilcoxon Signed Rank Test dan Confirmatory Factor Analysis (CFA). Penelitian ini menggunakan tingkat kepercayaan 95\%. Penggunaan Wilcoxon Signed Rank Test dalam penelitian ini adalah untuk mengetahui ada tidaknya perbedaan kualitas dari sekolah unggulan sebelum dan setelah diberlakukannya sistem zonasi. Tahapan-tahapan pengujian:

1. Menentukan hipotesis.

$\mathrm{H}_{0}$ : Tidak terdapat perbedaan sebelum dan setelah diberlakukannya sistem zonasi

$\mathrm{H}_{1}$ : Terdapat perbedaan sebelum dan setelah diberlakukannya sistem zonasi

2. Menghitung selisih skor $(d=$ sebelum zonasi - setelah zonasi).

3. Mengurutkan dengan memberi ranking selisih tersebut tanpa memperhatikan tandanya. Jika nilai $d_{i}$ sama, maka ranking dengan menggunakan rata-rata ranking.

4. Memberi tanda "+" atau "_-" pada ranking sesuai dengan tanda pada nilai $d_{i}$.

5. Menentukan nilai $\mathrm{N}, \mathrm{N}$ yaitu banyaknya nilai $d_{\mathrm{i}}$ yang bukan nol.

6. Menentukan jumlah $\mathrm{T}$ sebagai nilai statistik ujinya. T adalah jumlah ranking yang terkecil diantara kedua tanda (+ ; -).

7. Menentukan titik kritis $\mathrm{T}$ dengan menggunakan tabel Wilcoxon.

8. Membuat keputusan dan kesimpulan. Jika $\mathrm{T}_{\text {hitung }} \leq \mathrm{T}_{\text {tabel }}$, maka tolak $\mathrm{H}_{0}$ (Siegel, 1956).

Pramana et al. (2018), penggunaan CFA adalah untuk mengkonfirmasi pola hubungan antar variabel yang sudah diformulasikan dalam sebuah teori. Adapun langkah-langkahnya sebagai berikut:

1. Melakukan Bartlett Test of Sphericity untuk melihat korelasi antar variabel.

$\mathrm{H}_{0}$ : Matriks korelasi adalah matriks indentitas (tidak terdapat korelasi antar variabel yang signifikan)

$\mathrm{H}_{1}$ : Matriks korelasi bukan matriks indentitas (terdapat korelasi antar variable yang signifikan)

Statistik uji yang digunakan:

$X_{o b s}^{2}=-\left[n-1-\frac{1}{6}(2 p+5)\right] \ln |R|$

dimana:

$\mathrm{n}=$ jumlah observasi

$\mathrm{p}=$ jumlah variabel yang digunakan

$|\mathrm{R}|=$ determinan matriks korelasi

Pengujian akan tolak $\mathrm{H}_{0}$ pada tingkat signifikansi $\alpha$ jika $X_{o b s}^{2} \leq X_{\frac{1}{2}}^{2} p(p-1)$. 
2. Kaiser-Meyer-Olkin (KMO) dan Measurement of Sampling Adequacy (MSA) yang dihasilkan harus lebih dari 0,5

$\begin{aligned} K M O & =\frac{\sum_{i}^{P d} \sum_{i \neq j}^{P d} r_{i j}^{2}}{\sum_{i}^{P d} \sum_{i \neq j}^{P d} r_{i j}^{2}+\sum_{i}^{P d} \sum_{i \neq j}^{P d} a_{i j}^{2}} \\ M S A & =\frac{\sum_{i} r_{i j}^{2}}{\sum_{i} r_{i j}^{2}+\sum_{i} a_{i j}^{2}} \ldots \ldots \ldots \ldots \ldots \ldots\end{aligned}$

dimana:

$r_{i j}=$ koefisien korelasi sederhana antara variabel i dan $\mathrm{j}$

$a_{i j}=$ koefisien korelasi parsial antara variabel $\mathrm{i}$ dan $\mathrm{j}$

$\mathrm{Pd}=$ jumlah variabel setiap dimensi

Jika MSA setiap variabel ada yang kurang dari 0,50, maka variabel tersebut akan dikeluarkan dari analisis. Jika terdapat lebih dari satu variabel yang memiliki MSA kurang dari 0,50, maka variabel tersebut akan dikeluarkan dari analisis secara satu per satu dimulai dari MSA yang terkecil (Hair et al., 2014).

3. Pembentukan faktor dengan menggunakan metode Principal Component Analysis (PCA).

4. Menentukan jumlah faktor dengan berdasarkan nilai eigen yang lebih dari 1.

5. Melakukan rotasi faktor dengan rotasi orthogonal varimax.

\section{Data dan Sumber Data}

Penelitian ini dilaksanakan di SMPN 1 Banyuwangi dengan populasinya adalah semua guru yang sudah mengajar sejak sebelum diberlakukannya sistem zonasi dan masih aktif mengajar hingga saat ini. Jumlah guru yang aktif mengajar di SMPN 1 Banyuwangi pada tahun ajaran 2020/2021 sebanyak 34 orang, namun 12 orang diantaranya baru mengajar setelah diberlakukannya sistem zonasi. Dengan demikian, 22 orang akan menjadi populasi sekaligus responden pada penelitian ini. Data diperoleh dengan cara memberikan kuesioner dan diisi secara langsung oleh responden. Akibat tingginya angka Covid-19 saat periode pengambilan data, maka sebagian data dikumpulkan melalui google form dan sebagian yang lain dikumpulkan dengan sistem DOPU (drop off pick up). Kuesioner yang digunakan merupakan modifikasi kuesioner penelitian Yulista (2015) dan Ade Sasnita (2018) dan telah diuji validitas dan reliabilitasnya. Kuesioner dalam penelitian ini menggunakan pernyataan positif dengan skala sangat setuju, setuju, kurang setuju, tidak setuju, dan sangat tidak setuju dengan skor bernilai 5-1. Variabel yang digunakan terdiri dari empat dimensi yaitu sarana dan prasarana, guru, manajemen sekolah, dan proses pembelajaran. Dimensi sarana dan prasarana terdiri dari indikator prasarana sekolah dan sarana sekolah. Dimensi guru terdiri dari indikator kompetensi kepribadian, kompetensi pedagogik, dan kompetensi profesional. Dimensi manajemen sekolah terdiri dari indikator manajemen kurikulum, manajemen guru, manajemen keuangan, dan manajemen kesiswaan. Sementara indikator penyusun dimensi proses pembelajaran antara lain indikator pengembangan sikap, pengembangan keterampilan, dan pengembangan pengetahuan.

\section{HASIL DAN PEMBAHASAN}

\section{Gambaran Umum Guru SMPN 1 Banyuwangi}

Rata-rata usia dari 22 guru yang menjadi responden yakni 47,5 tahun. Guru termuda yang menjadi responden dalam penelitian ini berusia 26 tahun, sedangkan yang tertua berusia 59 tahun. Guru di SMPN 1 Banyuwangi memiliki usia yang bervariasi dengan standar deviasi sebesar 10,40. Dari Gambar 2 dapat dilihat bahwa cukup terdapat banyak guru yang mendekati usia pensiun. Hal ini menandakan bahwa di SMPN 1 Banyuwangi terdapat cukup banyak guru yang telah memiliki pengalaman mengajar yang cukup lama.

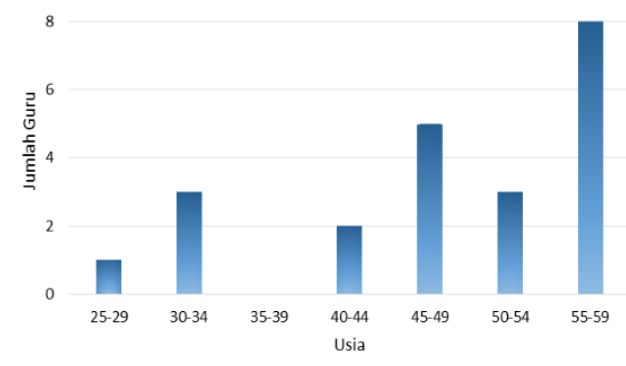

Gambar 2. Jumlah guru SMPN 1 Banyuwangi berdasarkan usia. 
Dari segi jenis kelamin, mayoritas guru yang menjadi responden dalam penelitian ini berjenis kelamin perempuan yakni sebesar 59 persen dan 41 persen sisanya berjenis kelamin laki-laki. Perbedaan yang cukup signifikan terjadi pada karakteristik status kepegawaian. Terdapat 86 persen guru memiliki status kepegawaian sebagai PNS, sedangkan 14 persen yang lain status kepegawaiannya sebagai non-PNS. Jika dilihat dari karakteristik pendidikan terakhir yang ditamatkan, semua guru SMPN 1 Banyuwangi yang menjadi responden memiliki gelar sarjana. 68 persen guru memiliki pendidikan terakhir setara dengan S1, dan 32 persen yang lain sudah berpendidikan S2. Hal ini cukup menggambarkan bahwa guru yang mengajar di SMPN 1 Banyuwangi sudah memenuhi standar kualifikasi akademik dan kompetensi nasional. Barwani dan Arifin (2017: 60) mengatakan bahwa guru pada jenjang pendidikan SMP/MTs harus memiliki kualifikasi akademik setara dengan S1.

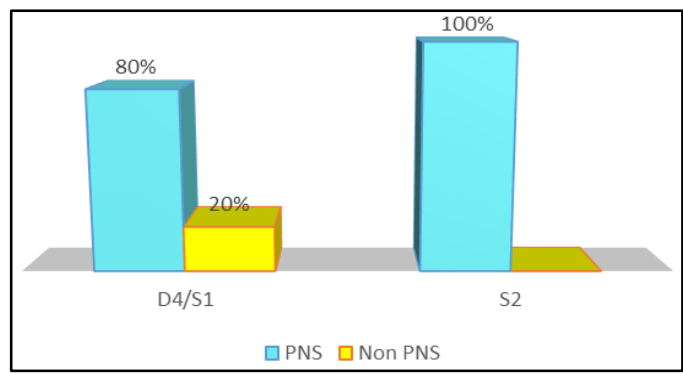

Gambar 3. Persentase guru SMPN 1 Banyuwangi berdasarkan pendidikan dan status kepegawaian.

Berdasarkan Gambar 3 terlihat bahwa guru yang memiliki pendidikan S2 sudah berstatus PNS semua, dan untuk kategori D4/S1 hanya 20 persen yang berstatus non-PNS. Guru yang telah memiliki status kepegawaian sebagai PNS ini memang usianya sudah diatas 30 tahun, sedangkan yang belum menjadi PNS usianya masih tergolong muda. Kemudahan untuk menjadi PNS pada masa sekarang sudah tidak seperti dulu, sehingga wajar jika guru yang masih muda tersebut tidak berstatus PNS. Badan Kepegawaian Negara (BKN) mengumumkan bahwa mulai tahun 2021 guru tidak akan masuk kategori PNS lagi, melainkan Pegawai Pemerintah dengan Perjanjian Kerja (PPPK). Banyaknya guru yang telah berstatus sebagai PNS ini menunjukkan bahwa sekolah SMPN 1 Banyuwangi telah memiliki guru yang berkualitas yang mampu meningkatkan kualitas murid dan sekolah. Hal ini didasarkan pada penelitian Sa'adah et al. (2018) yang mengatakan bahwa terdapat perbedaan kinerja antara guru PNS dengan guru non PNS, dimana rata-rata kinerja guru PNS lebih tinggi dibandingkan guru non PNS. Sedangkan Gambar 4 menunjukkan bahwa guru yang menjadi responden dalam penelitian ini sudah mewakili semua mata pelajaran yang ada di SMPN 1 Banyuwangi.

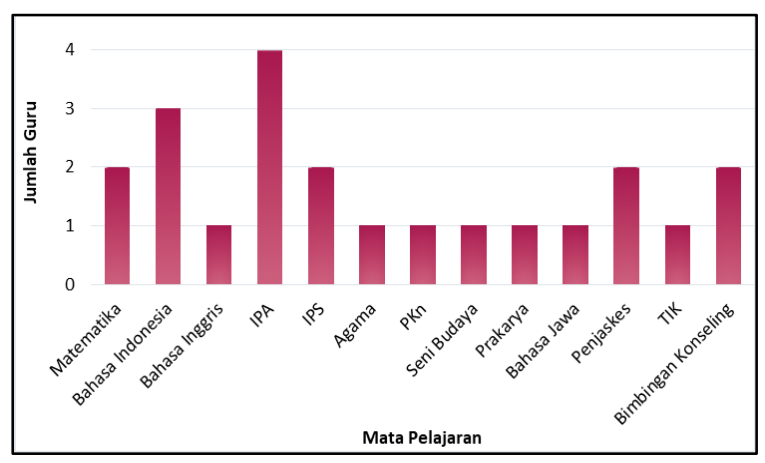

Gambar 4. Jumlah guru SMPN 1 Banyuwangi berdasarkan mata pelajaran.

\section{Perbandingan Kualitas Sekolah SMPN 1 Banyuwangi Sebelum dan Setelah Diberlakukannya Sistem Zonasi}

Berdasarkan hasil olahan data, penilaian responden untuk dimensi sarana dan prasarana sekolah sudah cukup tinggi. Semakin tinggi skor penilaian berarti semakin baik kualitasnya. Terdapat beberapa penilaian responden yang mencapai skor maksimum, baik pada saat sebelum zonasi, maupun setelah zonasi. Tetapi pada saat setelah zonasi, penilaian responden yang mencapai nilai maksimum tidak sebanyak saat sebelum zonasi. Oleh karena itu, total skor penilaian sarana dan prasarana setelah zonasi lebih rendah dibandingkan dengan total skor penilaian sebelum zonasi (Gambar 5). Butir pertanyaan sarana dan prasarana yang memiliki penurunan skor penilaian yang cukup tinggi adalah tentang kebersihan ruang kelas, kondisi media pembelajaran dan ketersediaan alat kebersihan di kelas. Hal ini dapat terjadi dikarenakan mungkin tingkat 
kepedulian dari siswa setelah zonasi tidak setinggi siswa sebelum zonasi dalam hal menjaga kondisi kelas, buku maupun media pembelajaran yang lain. Sebab, siswa bertanggung jawab akan kebersihan kelasnya dengan melaksanakan piket serta bertanggung jawab untuk menjaga buku yang dipinjamkan oleh sekolah.

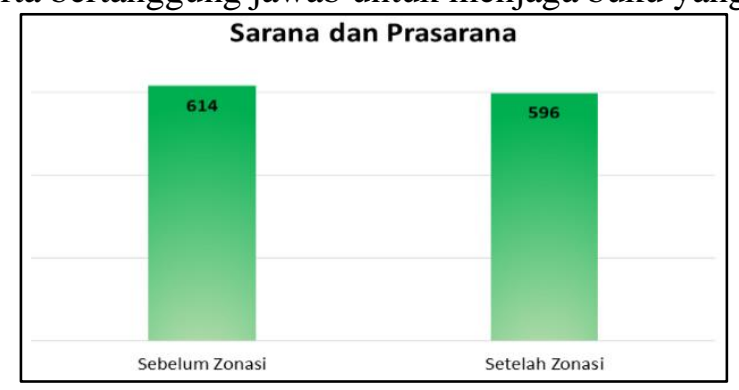

Gambar 5. Grafik total skor penilaian sarana dan prasarana sekolah.

Pada dimensi guru hanya terdapat tiga responden yang memberikan nilai maksimum untuk kondisi sebelum zonasi dan satu responden yang memberikan nilai maksimum untuk kondisi setelah zonasi. Perbedaan yang tidak terlalu mencolok ini dikarenakan guru tersebut merupakan orang yang sama pada saat sebelum dan setelah diberlakukannya zonasi. Sehingga perilaku dan kebiasaannya dalam mengajar tidak akan jauh berbeda. Meskipun tidak terlalu signifikan, penurunan skor penilaian yang paling tinggi terjadi pada butir pertanyaan mengenai penguasaan kelas, penggunaan teknologi serta media pembelajaran berupa audio visual. Sejalan dengan penelitian yang dilakukan oleh Ula dan Lestari (2020) bahwa setelah diberlakukannya sistem zonasi, guru menjadi kesulitan dalam menguasai kondisi kelas karena tantangan dalam mengajar anak dengan kemampuan yang beragam lebih berat daripada anak dengan kemampuan yang relatif homogen. Nurlailiyah (2019) mengatakan bahwa dengan diberlakukannya sistem zonasi, guru lebih mengajarkan etika dan sopan santun dibandingkan dengan materi pelajaran. Sesuai dengan hasil penelitian ini yang menunjukkan bahwa penggunaan teknologi dan media pembelajaran setelah zonasi mengalami penurunan.

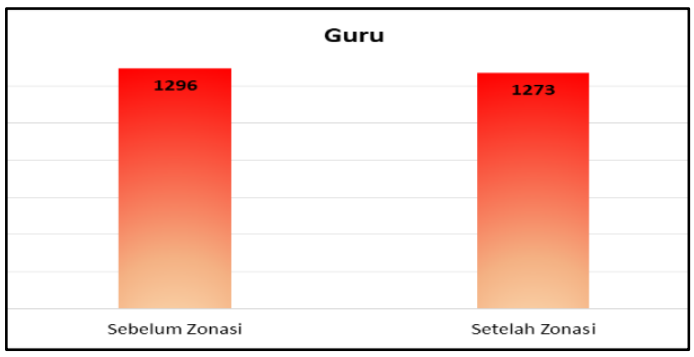

Gambar 6. Grafik total skor penilaian guru sekolah.

Pada manajemen sekolah, responden yang memberikan skor penilaian maksimum pada saat setelah zonasi tidak sebanyak pada sebelum zonasi. Namun, total skor penilaian yang diperoleh sebelum zonasi dan setelah zonasi tidak berbeda terlalu jauh (Gambar 7). Sebab sistem zonasi hanya mengubah kebijakan mengenai prosedur penerimaan peserta didik baru dan tidak mengubah kebijakan yang telah ditetapkan sekolah dalam hal kegiatan belajar mengajar. Penurunan skor yang terjadi pada penilaian manajemen sekolah diperkirakan akibat kebijakan sekolah yang tetap, sehingga tidak dapat mengakomodasi seluruh peserta didiknya. Sebab penurunan skor penilaian tertinggi terjadi pada butir pertanyaan tentang ketersediaan ekstrakurikuler di sekolah. Penerapan sistem zonasi memungkinkan sekolah untuk menerima peserta didik dengan berbagai jenis minat dan bakat. Karena kemampuan akademik sudah tidak diperhitungkan lagi, maka besar kemungkinan siswa memiliki minat dan bakat dalam bidang nonakademik. Tetapi, kegiatan ekstrakurikuler nonakademik yang tersedia masih sama dengan sebelumnya, sehingga besar kemungkinan minat dan bakat yang dimiliki siswa tidak tertampung oleh kegiatan ekstrakurikuler yang sudah ada. 


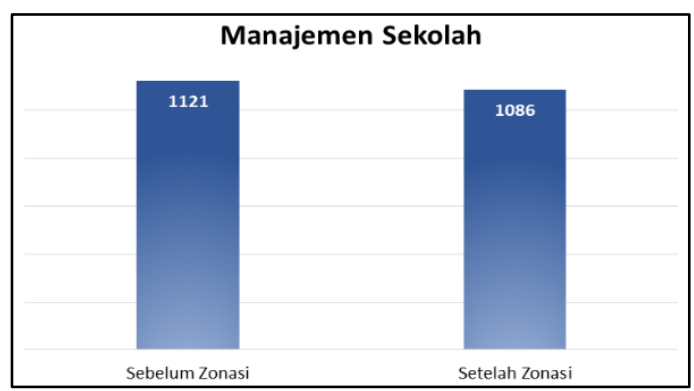

Gambar 7. Grafik total skor penilaian manajemen sekolah.

Total skor penilaian responden untuk proses pembelajaran pada saat sebelum dan setelah zonasi terlihat cukup berbeda pada Gambar 8. Pada saat sebelum zonasi, banyak responden yang memberikan nilai maksimum. Sedangkan pada saat setelah zonasi tidak ada responden yang memberikan skor penilaian maksimum. Penurunan skor penilaian terjadi pada semua butir pertanyaan dalam dimensi ini. Penurunan skor tertinggi terjadi pada butir pertanyaan mengenai kemampuan siswa dalam memahami materi pelajaran. Sesuai dengan hasil penelitian yang dilakukan oleh Nurlailiyah (2019) bahwa terdapat banyak siswa yang nilainya masih di bawah standar minimum. Selain itu, penurunan skor yang tergolong tinggi juga terjadi pada butir pertanyaan tentang nilai yang diperoleh siswa dan sikap siswa saat kegiatan belajar mengajar. Hal ini sesuai dengan penelitian sebelumnya yang dilakukan oleh Nurlailiyah (2019) serta Ula dan Lestari (2020) bahwa siswa yang masuk setelah diberlakukannya sistem zonasi lebih susah disiplin dan ramai di dalam kelas. Sikap ramai di kelas bisa jadi akibat dari beragamnya kemampuan siswa dalam memahami materi. Ketika guru mengulang penjelasan materi, maka siswa yang memiliki kemampuan tinggi akan menunggu dan merasa bosan. Dengan begitu mereka akan melakukan aktivitas sendiri atau bahkan berbincang dengan temannya. Sebaliknya, ketika guru menjelaskan materi baru dan siswa dengan kemampuan rendah tidak dapat mengikutinya, maka mereka juga akan melakukan aktivitas sendiri dan menimbulkan kegaduhan. Sebab, anakanak berkemampuan tinggi membutuhkan pengayaan dan tantangan yang baru dari guru, sedangkan anak-anak berkemampuan rendah masih membutuhkan bantuan (Ula dan Lestari, 2020).

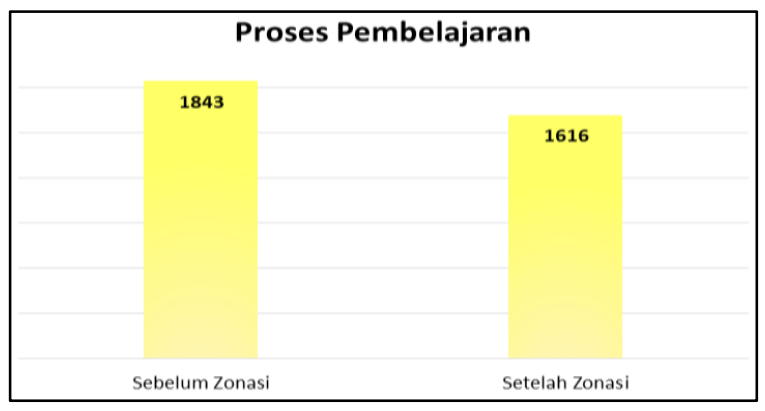

Gambar 8. Grafik total skor penilaian proses pembelajaran.

Berdasarkan hasil di atas diketahui bahwa terdapat perbedaan skor penilaian antara sebelum dan setelah adanya sistem zonasi. Untuk melihat signifikansi perbedaan tersebut maka dilakukan pengujian dengan menggunakan Wilcoxon Signed Rank Test.

Tabel 1. Wilcoxon Signed Rank Test.

\begin{tabular}{lccc}
\hline \multicolumn{1}{c}{ Dimensi } & $\mathrm{T}$ & $\mathrm{T}_{\text {tabel }}$ & Sig. (2-tailed) \\
\hline Sarana dan Prasarana & 13,5 & 8 & 0,148 \\
Guru & 25 & 17 & 0,149 \\
Manajemen Sekolah & 15 & 11 & 0,109 \\
Proses Pembelajaran & 0 & 35 & 0,000 \\
\hline
\end{tabular}

Hasil yang diperoleh yaitu hanya dimensi proses pembelajaran saja yang berbeda secara signifikan antara sebelum dengan setelah diberlakukannya sistem zonasi. Dimana dalam proses pembelajaran, kelas menjadi lebih ramai akibat siswa kurang disiplin dan tidak bersikap tenang. Selain itu kemampuan dalam memahami pelajaran tidak sebaik siswa sebelum sistem zonasi diberlakukan. Sistem zonasi memang tidak mengubah kebijakan atau segala sesuatu yang sudah ada di sekolah. Sistem zonasi hanya mengubah kebijakan mengenai prosedur penerimaan peserta didik baru. Sesuai dengan hal itu, maka memang sarana dan prasarana, guru, serta 
manajemen sekolah yang telah ada sebelumnya tidak mengalami perubahan setelah diberlakukannya sistem zonasi. Sehingga sejalan dengan hasil pengujian yang memutuskan bahwa sarana dan prasarana, guru, serta manajemen sekolah tidak berbeda secara signifikan antara sebelum dan setelah zonasi.

\section{Dimensi dan Indikator Kualitas Sekolah Unggulan}

Setelah membandingkan kualitas sekolah unggulan SMPN 1 Banyuwangi di Kabupaten Banyuwangi pada saat sebelum dan setelah diberlakukannya sistem zonasi, penelitian ini melakukan konfirmasi terhadap indikator dan dimensi kualitas sekolah unggulan dengan menggunakan analisis faktor konfirmatori. Sebelum melakukan analisis, variabel observasi yang berupa indikator dan dimensi harus memenuhi asumsi yang berlaku yakni uji Bartlett dan Keiser-Meyer-Olkin Measurement of Sampling Adequacy (KMO-MSA). Selain itu, variabel observasi harus memiliki total variance explained minimal 50 persen dan nilai communality lebih atau sama dengan 0,5 (Hair et al. 2014).

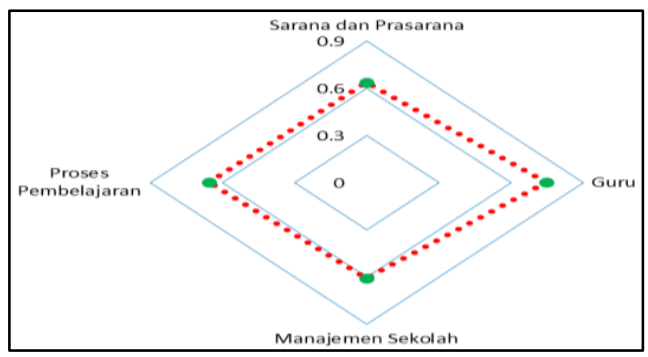

Gambar 9. Diagram radar nilai communality setiap dimensi.

Hasil konfirmasi dimensi sarana dan prasarana, guru, manajemen sekolah dan proses pembelajaran dengan analisis faktor diperoleh bahwa keempat dimensi tersebut dapat membentuk konsep kualitas sekolah. Berdasarkan Gambar 9, dapat dilihat bahwa dimensi guru yang paling mencirikan kualitas sekolah. Hal ini didasarkan pada nilai communality dimensi guru yang paling tinggi yakni sebesar 0,746. Nilai communality adalah total varians dari variabel observasi yang dijelaskan oleh faktor yang terbentuk (Santos et al., 2019). Semakin besar nilai communality, maka dimensi tersebut semakin mencirikan kualitas sekolah.

Tabel 2. Hasil analisis faktor konfirmatori berdasarkan dimensi kualitas sekolah.

\begin{tabular}{|c|c|c|c|c|c|c|}
\hline Dimensi & KMO & Bartlett's Test & MSA & Communality & Loading Factor & TVE (persen) \\
\hline Sarana dan Prasarana & \multirow{4}{*}{0,716} & \multirow{4}{*}{0,000} & 0,709 & 0,637 & 0,798 & \multirow{4}{*}{66,196} \\
\hline Guru & & & 0,702 & 0,746 & 0,864 & \\
\hline Manajemen Sekolah & & & 0,693 & 0,609 & 0,780 & \\
\hline Proses Pembelajaran & & & 0,768 & 0,656 & 0,810 & \\
\hline
\end{tabular}

Nilai loading factor merupakan nilai yang menunjukkan besarnya korelasi antara variabel observasi dengan faktor yang terbentuk. Sebanding dengan besar nilai communality, pada Tabel 2 guru memiliki nilai loading factor yang terbesar. Hal ini menunjukkan bahwa guru memiliki korelasi yang kuat dengan kualitas sekolah. Selain guru, ketiga dimensi yang lain juga memiliki korelasi yang kuat dengan kualitas sekolah dengan nilai loading factor lebih dari 0,7 .

Tabel 3. Hasil analisis faktor konfirmatori setiap dimensi berdasarkan indikator penyusun.

\begin{tabular}{|c|c|c|c|c|c|c|c|}
\hline Dimensi & Indikator & KMO & $\begin{array}{c}\text { Bartlett's } \\
\text { Test }\end{array}$ & MSA & Communality & $\begin{array}{l}\text { Loading } \\
\text { Factor }\end{array}$ & $\begin{array}{c}\text { TVE } \\
\text { (persen) }\end{array}$ \\
\hline \multirow{2}{*}{$\begin{array}{l}\text { Sarana dan } \\
\text { Prasarana }\end{array}$} & Sarana & \multirow{2}{*}{0,500} & \multirow{2}{*}{0,000} & 0,500 & 0,834 & 0,914 & \multirow{2}{*}{83,449} \\
\hline & Prasarana & & & 0,500 & 0,834 & 0,914 & \\
\hline \multirow{3}{*}{ Guru } & Kompetensi Kepribadian & \multirow{3}{*}{0,684} & \multirow{3}{*}{0,000} & 0,708 & 0,719 & 0,848 & \multirow{3}{*}{74,475} \\
\hline & Kompetensi Pedagogik & & & 0,737 & 0,692 & 0,832 & \\
\hline & Kompetensi Profesional & & & 0,633 & 0,824 & 0,908 & \\
\hline \multirow{4}{*}{$\begin{array}{l}\text { Manajemen } \\
\text { Sekolah }\end{array}$} & Manajemen Kurikulum & \multirow{4}{*}{0,817} & \multirow{4}{*}{0,000} & 0,789 & 0,787 & 0,887 & \multirow{4}{*}{71,623} \\
\hline & Manajemen Guru & & & 0,863 & 0,614 & 0,784 & \\
\hline & Manajemen Keuangan & & & 0,800 & 0,765 & 0,874 & \\
\hline & Manajemen Kesiswaan & & & 0,835 & 0,699 & 0,836 & \\
\hline \multirow{3}{*}{$\begin{array}{l}\text { Proses } \\
\text { Pembelajaran }\end{array}$} & Pengembangan Sikap & \multirow{3}{*}{0,776} & \multirow{3}{*}{0,000} & 0,804 & 0,934 & 0,966 & \multirow{3}{*}{94,078} \\
\hline & Pengembangan Keterampilan & & & 0,729 & 0,954 & 0,977 & \\
\hline & Pengembangan Pengetahuan & & & 0,802 & 0,935 & 0,967 & \\
\hline
\end{tabular}


Hasil analisis faktor konfirmatori terhadap indikator penyusun masing-masing dimensi diperoleh bahwa setiap indikator tersebut dapat membentuk konsep dimensinya (Tabel 3). Indikator pada sarana dan prasarana sama-sama memiliki nilai communality sebesar 0,834 dan nilai loading factor yang cukup tinggi yakni sebesar 0,914. Pada guru, indikator yang paling mencirikan yaitu indikator kompetensi profesional dengan nilai communality tertinggi yaitu 0,824 . Indikator yang kurang mencirikan guru dan memiliki nilai communality 0,692 yaitu indikator kompetensi pedagogik, sementara indikator kompetensi kepribadian memiliki nilai communality 0,719 . Besar nilai loading factor dari ketiga indikator pada guru juga sebanding dengan nilai communality yang diperoleh. Nilai loading factor tertinggi diperoleh indikator kompetensi profesional $(0,908)$, diikuti oleh kompetensi kepribadian $(0,848)$ dan kompetensi pedagogik $(0,832)$. Pada manajemen sekolah, indikator yang paling mencirikan yaitu indikator manajemen kurikulum dengan nilai communality 0,787 dan yang paling kurang mencirikan yaitu indikator manajemen guru dengan nilai communality 0,614 . Sedangkan indikator manajemen keuangan dan manajemen kesiswaan memiliki nilai communality 0,765 dan 0,699. Korelasi keempat indikator dengan manajemen sekolah cukup tinggi dengan nilai loading factor lebih dari 0,7. Untuk proses pembelajaran, indikator yang paling mencirikan proses pembelajaran adalah indikator pengembangan keterampilan, diikuti oleh indikator pengembangan pengetahuan dan pengembangan sikap dengan nilai communality sebesar 0,$954 ; 0,935$; dan 0,934 . Ketiga indikator memiliki korelasi yang kuat dengan proses pembelajaran, nilai loading factor semua indikatornya lebih dari 0,9.

\section{KESIMPULAN}

Pada saat sebelum zonasi terdapat banyak skor penilaian yang mencapai nilai maksimum, sementara setelah zonasi banyak yang mengalami penurunan skor penilaian. Penurunan skor tertinggi pada sarana dan prasarana terjadi pada butir pertanyaan mengenai kebersihan ruang kelas, kondisi media pembelajaran dan ketersediaan alat kebersihan di kelas. Pada guru, butir pertanyaan yang mengalami penurunan skor tertinggi yaitu penguasaan kelas, penggunaan teknologi serta media pembelajaran berupa audio visual. Untuk manajemen sekolah, penurunan skor tertinggi terjadi pada butir pertanyaan mengenai ketersediaan ekstrakurikuler di sekolah. Sementara butir pertanyaan pada proses pembelajaran yang banyak mengalami penurunan skor yaitu tentang kemampuan siswa dalam memahami materi pelajaran, nilai yang diperoleh siswa dan sikap siswa saat kegiatan belajar mengajar.

Perbedaan kualitas sekolah unggulan SMPN 1 Banyuwangi di Kabupaten Banyuwangi antara sebelum dan setelah diberlakukannya sistem zonasi hanya terjadi pada proses pembelajaran. Sedangkan sarana dan prasarana, guru, serta manajemen sekolah tidak terdapat perbedaan antara sebelum dan setelah diberlakukannya sistem zonasi.

Guru merupakan dimensi yang paling mencirikan dan memiliki korelasi kuat dengan kualitas sekolah unggulan SMPN 1 Banyuwangi di Kabupaten Banyuwangi, diikuti oleh dimensi proses pembelajaran, sarana dan prasarana, serta manajemen sekolah.

\section{DAFTAR PUSTAKA}

Badan Perencanaan Pembangunan Nasional. (2020). Indeks Pembangunan Pemuda Indonesia 2019. Jakarta: Bappenas.

Badan Pusat Statistik. (2018). Statistik Pendidikan 2018. Jakarta: BPS.

Badan Pusat Statistik. (2019). Indeks Pembangunan Manusia Jawa Timur 2019. Jawa Timur: BPS Provinsi Jawa Timur.

Badan Pusat Statistik. (2020). Statistik Pendidikan Provinsi Jawa Timur 2019. Jawa Timur: BPS Provinsi Jawa Timur.

Barwani \& Arifin, M. (2017). Sistem penjaminan mutu pendidikan: Teori dan praktik. Yogyakarta: Ar-Ruzz Media.

Hair et al. (2014). Pearson new international edition. United State of America: Pearson Education Limited.

Hana, O. D. B. (31 Desember 2020). "Guru Tak Masuk Kategori CPNS 2021, PGRI Sebut Ada Diskriminasi". Kabar24. Diakses pada 10 Juli 2021, dari https://kabar24.bisnis.com/read/20201231/79/1337254/gurutak-masuk-kategori-cpns-2021-pgri-sebut-ada-diskriminasi

Hidayat, Edi. (2014) Faktor-faktor yang mempengaruhi mutu sekolah (pengaruh dari faktor kinerja mengajar guru dan pemanfaatan sumber belajar). Jurnal Administrasi Pendidikan, 21(1).

Kementrian Pendidikan dan Kebudayaan. (17 Agustus 2018). "Tingkatkan Mutu Pendidikan Melalui Empat Hal Ini”. Diakses pada 24 Juli 2021, dari https://www.kemdikbud.go.id/main/blog/2018/08/tingkatkanmutu-pendidikan-melalui-empat-hal-ini 
Kementerian Pendidikan dan Kebudayaan. Dashboard Guru dan Tenaga Pendidik. Diakses pada 28 April 2021 , https://referensi.data.kemdikbud.go.id/dashboardgtk/ptk_dash21.php?id=20\&kd=rRkvQFADIEX28W7 Fub5YfHKy1XcJKP0JgsW63LXSSLQ=

Kementerian Pendidikan dan Kebudayaan. Data Referensi. Diakses pada 28 April 2021, dari https://referensi.data.kemdikbud.go.id/index11_smp.php?kode=052500\&level=2

Kementrian Pendidikan dan Kebudayaan. Neraca Pendidikan Daerah. Diakses pada 24 Juli 2021, dari https://npd.kemdikbud.go.id/?

Murniarti, D. et al. (2016). Pengaruh sarana dan prasarana terhadap hasil belajar siswa pelajaran ekonomi SMA Negeri 1 Sungai Ambawang. Jurnal Pendidikan Dan Pembelajaran Khatulistiwa, 5(11), 2-13.

Nurkuntari, Yuni. (2016) Pengaruh manajemen sekolah terhadap mutu pendidikan sekolah menengah atas di Kota Semarang. Jurnal Value Added: Majalah Ekonomi dan Bisnis, 12(2), 85-100.

Nurlailiyah, Aris. (2019). Analisis kebijakan sistem zonasi terhadap perilaku siswa SMP di Yogyakarta. Realita, 17(1), 13-21.

Nur, M., Harun, C.Z. \& Ibrahim, S. (2016). Manajemen sekolah dalam meningkatkan mutu pendidikan pada SDN Dayah Guci Kabupaten Pidie. Jurnal Administrasi Pendidikan Pascasarjana Universitas Syiah Kuala, 4(1), 93-103.

Pradewi, G. I. \& Rukiyati. (2019). Kebijakan sistem zonasi dalam perspektif pendidikan. Jurnal Manajemen dan Supervisi Pendidikan, 4(1), 28-34.

Pramana, Setia et al. (2018). Data mining dengan R konsep serta implementasi. Bogor: In Media.

Saputra, K. Y. (2015). Pengaruh proses pembelajaran dan motivasi belajar terhadap hasil belajar IPS siswa SMP Maulana Pegayaman. Jurnal Jurusan Pendidikan Ekonomi (JJPE), 5(1).

Sasnita, Ade. (2018). Pengaruh perilaku siswa terhadap hasil belajar PAI di SMP Negeri 6 Banda Aceh [Skripsi]. Banda Aceh: Universitas Islam Negeri Ar-Raniry

Sa'adah et al. (2018). Studi komparatif tentang perbedaan kinerja guru PKN PNS dengan NON PNS (Studi pada SMP Di Kota Singaraja). e-Journal Program Sarjana 1 Universitas Pendidikan Ganesha Program Studi Pendidikan Pancasila dan Kewarganegaraan, 1-10.

Siegel, Sidney. (1956). Nonparametric statistics for the behavioral sciences. New York: McGraw Hill Book Company, Inc.

Supardi, U. S. (2015). Arah pendidikan di Indonesia dalam tataran kebijakan dan implementasi. Jurnal Formatif, 2(2): 111-121.

United Nations Development. (2020). Education Index. Diakses pada 27 April 2020, dari http://hdr.undp.org/en/indicators/103706\#

Widyastuti, R.T. (2020). Dampak pemberlakuan sistem zonasi terhadap mutu sekolah dan peserta didik. Edusaintek: Jurnal Pendidikan Sains dan Teknologi, 7(1), 11-19.

Yulista. (2015). Kualitas layanan pendidikan di Sekolah Menengah Kejuruan Muhammadiyah Batang (tahun ajaran 2014/2015) [Skripsi]. Semarang: Universitas Negeri Semarang. 